\title{
Investigating Outcomes of T-Government Using a Public Value Management Approach
}

\author{
Anne Fleur van Veenstra and Marijn Janssen \\ Faculty of Technology, Policy and Management, Delft University of Technology, \\ Jaffalaan 5, 2628 BX Delft, The Netherlands \\ \{a.f.e.vanveenstra,m.f.w.h.a.janssen\}@tudelft.nl
}

\begin{abstract}
A main objective of transformational government (t-government) is to realize public sector reform. Initiatives of public sector reform, commonly referred to as New Public Management (NPM), often failed to achieve the desired results and led to undesired outcomes. Hence, a new reform approach, referred to as Public Value Management (PVM), emerged to overcome these negative effects and to which the use of information technology (IT) is central. This paper investigates a t-government effort in the Netherlands to find whether it realizes the objectives of PVM. The findings of the case study show that $\mathrm{t}$ government does not achieve these objectives. Instead of realizing a transformed organizational structure, t-government is found to be concerned with setting up governance among the different parties in a in network to allow for collaboration. Furthermore, the case study results show that to realize the outcomes of PVM, t-government needs to be accompanied by a professionalization of the work force and by making government processes more transparent to ensure public accountability.
\end{abstract}

Keywords: Transformational government, T-Government, E-Government, Public Value Management, New Public Management, Public Sector Reform.

\section{Introduction}

Transformational government (t-government) efforts aim to move beyond the egovernment efforts of creating better service delivery for citizens and businesses, and realize public sector reform [1-3]. The link between e-government and public sector change was first made in the mid-1990's, when "ICTs began to be viewed as strategic assets for government with the potential to help policy makers and program managers redesign and integrate services to support critical stakeholder relationships and overarching policy goals" [2, p. S89]. More specifically, "e-Government is very often conceived as a powerful instrument to achieve the objectives envisaged by the new public management (NPM) ideology" [3, p. 53]. The NPM paradigm aimed to introduce private sector practices in the public sector to make government operations more cost-effective and customer-centered [4-7]. T-government efforts employ IT to radically change the public sector [8] and aim to make governments more effective. 
Both e-government and NPM are criticized for their failure to achieve many of the desired outcomes [4,5,7-10]. Rather than transforming public administration, egovernment efforts were found to reinforce the existing structure within government [9]. Many barriers still exist that inhibit the changes that are considered necessary to realize transformation [11]. As a response t-government was introduced concerning the use of IT to transform governments [8] and to capture a broader range of pubic values like accountability and transparency. A new approach to public sector reform emerged aiming to achieve more responsive and effective public administrations $[4,5,10,12-14]$. This reform approach is commonly referred to as Public Value Management (PVM) [5,12]. PVM refers to the continuous assessment of the actions that the public sector undertakes to ensure that public value is created [12]. Central to the paradigm is the use of IT to create public value for the customers of the government as well as to strengthen the role of government itself [15], through collaboration in networks [5].

The objective of this paper is to see whether t-government efforts realize the outcomes envisioned by PVM. By looking at an effort of t-government in the Netherlands, the outcomes are investigated to see whether they are in line with the objectives of PVM. T-government efforts aim for a process orientation, breaking down the barriers of the vertical bureaucracies [16]. Leveraging information technology (IT), they aim to make governments more effective and realize an overhaul of the public sector [8]. In this paper, t-government is investigated by looking at a case study in the Netherlands using a PVM approach. The next section introduces PVM and its objectives. In the third section the case methodology is presented, followed by the case study description. Subsequently, the findings from the case study are presented and discussed. Finally, the last section presents conclusions and recommendations for further research.

\section{Theoretic Background on Public Value Management (PVM)}

PVM aims to realize public sector reform [5,12]. Public sector reform "is usually thought of as a means to an end, not to an end in itself. [...] [Its objectives] include making savings (economies) in public expenditure, improving the quality of public services, making the operation of government more efficient, and increasing the chances that the policies which are chosen and implemented will be effective" [17, p. 6; emphases in original]. The objectives that are referred to, thus, span the width of governments' activities and purposes; including cost savings, outcomes that are to be achieved by the government and the values that are considered. Such change, however, is expected to take a long time: "The full benefits of major changes in the processes and structures of public agencies normally cannot be harvested until three, four, five, or even more years after a reform program has been launched" [17, p. 7].

PVM emerged as a reaction to its predecessor paradigm NPM as well as to the traditional Weberian bureaucracy to overcome the negative effects of both, such as the inefficiency and red-tape of bureaucracy and the fragmentation of government $[4,5,7,10]$. Traditionally, public administrations are characterized as hierarchical 
organizations with public officials carrying out predefined tasks: bureaucracies [18]. To understand the central notions of PVM, it is thus useful to compare it to both bureaucracy and NPM. The agendas of public sector reform can be seen to differ in a number of dimensions (see Table 1). Although these reform agendas clearly have a normative character [19], the purpose of this section is to describe their ideal type. An ideal type is a description of a specific phenomenon, not referring to an ideal situation seen from a normative standpoint. Traces of the ideal types of public organizations presented in this section are still found in today's public administrations [4].

Table 1. Comparison of the three public sector reform agendas [based on 4,5,10,12-14]

\begin{tabular}{|c|c|c|c|}
\hline & Bureaucracy & NPM & PVM \\
\hline $\begin{array}{l}\text { Main purpose of } \\
\text { public sector }\end{array}$ & $\begin{array}{l}\text { Realizing political } \\
\text { goals }\end{array}$ & $\begin{array}{l}\text { Mitigating market } \\
\text { failure }\end{array}$ & $\begin{array}{l}\text { Creating public } \\
\text { value }\end{array}$ \\
\hline $\begin{array}{l}\text { Role of the } \\
\text { government }\end{array}$ & $\begin{array}{l}\text { Policy-making and } \\
\text { implementation }\end{array}$ & $\begin{array}{l}\text { Catalyst for actions } \\
\text { of private parties }\end{array}$ & $\begin{array}{l}\text { Serving and } \\
\text { empowering }\end{array}$ \\
\hline Public sector ethos & $\begin{array}{l}\text { Public sector } \\
\text { monopoly }\end{array}$ & $\begin{array}{l}\text { Customer } \\
\text { satisfaction }\end{array}$ & $\begin{array}{l}\text { Dialogue and } \\
\text { collaboration }\end{array}$ \\
\hline $\begin{array}{l}\text { Formulation of } \\
\text { public value }\end{array}$ & $\begin{array}{l}\text { Politicians formulate } \\
\text { laws, consult experts }\end{array}$ & $\begin{array}{l}\text { Aggregation of } \\
\text { individual } \\
\text { preferences }\end{array}$ & $\begin{array}{l}\text { Complex process of } \\
\text { interactions; result of } \\
\text { dialogue }\end{array}$ \\
\hline Role of the public & $\begin{array}{l}\text { Clients and } \\
\text { electorate }\end{array}$ & Customers & Citizens \\
\hline $\begin{array}{l}\text { Role of public } \\
\text { officials }\end{array}$ & $\begin{array}{l}\text { Following } \\
\text { procedures }\end{array}$ & $\begin{array}{l}\text { Attaining output } \\
\text { targets }\end{array}$ & $\begin{array}{l}\text { Coordinating } \\
\text { networks }\end{array}$ \\
\hline $\begin{array}{l}\text { Discretion of } \\
\text { administrators }\end{array}$ & $\begin{array}{l}\text { Limited; } \\
\text { standardization of } \\
\text { tasks }\end{array}$ & $\begin{array}{l}\text { Room for attaining } \\
\text { entrepreneurial goals }\end{array}$ & $\begin{array}{l}\text { Discretion necessary; } \\
\text { limited by political } \\
\text { accountability }\end{array}$ \\
\hline $\begin{array}{l}\text { Motivation of } \\
\text { administrators }\end{array}$ & $\begin{array}{l}\text { Wages and status; } \\
\text { protected and } \\
\text { privileged profession }\end{array}$ & $\begin{array}{l}\text { Entrepreneurial } \\
\text { spirit; ideal of } \\
\text { smaller government }\end{array}$ & $\begin{array}{l}\text { Public service; } \\
\text { contributing to } \\
\text { society }\end{array}$ \\
\hline $\begin{array}{l}\text { Mechanisms for } \\
\text { achieving policy } \\
\text { objectives }\end{array}$ & $\begin{array}{l}\text { Implementing } \\
\text { government } \\
\text { programs }\end{array}$ & $\begin{array}{l}\text { Realizing policy } \\
\text { objectives by private } \\
\text { parties }\end{array}$ & $\begin{array}{l}\text { Networks of public } \\
\text { and private } \\
\text { organizations }\end{array}$ \\
\hline Accountability & $\begin{array}{l}\text { Hierarchical: } \\
\text { administrators are } \\
\text { accountable to } \\
\text { elected politicians }\end{array}$ & $\begin{array}{l}\text { Market-driven: } \\
\text { aggregation of } \\
\text { preferences leads to } \\
\text { desired output for } \\
\text { large groups of } \\
\text { customers, via } \\
\text { public-private } \\
\text { contacts }\end{array}$ & $\begin{array}{l}\text { Pluriform: } \\
\text { administrators have } \\
\text { to follow the law, } \\
\text { societal values, } \\
\text { political norms, } \\
\text { professional } \\
\text { standards and } \\
\text { citizens' interests }\end{array}$ \\
\hline $\begin{array}{l}\text { Organizational } \\
\text { structure; service } \\
\text { delivery }\end{array}$ & Hierarchical & $\begin{array}{l}\text { Private sector / } \\
\text { public agencies put } \\
\text { at a distance }\end{array}$ & Networks / pluriform \\
\hline
\end{tabular}

The three reform agendas differ on a range of characteristics. A first group of characteristics is concerned with the fundamentals of public administration: the purpose, role, and ethos of the public sector, and the way in which public value is 
formulated. In the bureaucratic ideal type public administrations have a monopoly on realizing political goals by policy-making and implementation $[4,5,13,20]$. Public value is thus formulated by politicians in consultation with experts [20]. Within NPM the purpose of the public sector is to mitigate market failure by coordinating the actions of private parties in order to satisfy the customers of the public sector [4$7,13,14]$. Public sector is defined using economic theory to aggregate the individual wishes of these customers [14]. In the PVM approach, public administrations aim for creating public value directly for citizens or by strengthening the role of the government $[5,12,15]$, thereby shifting their role to serving and empowering citizens and business to create public value [13]. Governments operating according to the PVM agenda thus focus on collaborating and creating a dialogue with citizens in order to determine what constitutes public value [5].

A second group of characteristics is related to the role of the public and public officials. While the public used to be seen by public administrations as having a passive role (clients, electorate) in a bureaucracy [19], their role was redefined as customers under the NPM paradigm [6,21]. Under the PVM paradigm they get the status of citizens that can also participate in government action [5]. This requires, in turn, a different role of public officials. Rather than professional bureaucrats executing predefined tasks and procedures, public officials under the NPM paradigm were expected to become entrepreneurial and more customer-friendly by achieving predefined output targets $[5,7,10]$. Within PVM, public value is realized when an adaptable, learning-based approach is taken on by public managers [12]. In order to realize public value, they coordinate the actions of both public and private parties within networks [5,12]. This can only be achieved when public officials have sufficient discretion to carry out their tasks [5,12].

The last group of characteristics is the organizational structure and the way in which the objectives of the public sector are realized. In the bureaucracy, actions are performed by a top-down division and aggregation of predefined tasks [18]. Subsequently, accountability is organized by administrators reporting to elected leaders, while the administrators themselves are expected to remain impartial [5]. This form of accountability is often called 'procedure accountability', in which administrators are mainly responsible for following the right procedures [22]. Accountability shifted from procedure accountability towards clearly defined goals to assure their delivery in the NPM paradigm [22]. Public officials now were not only responsible for following the right procedure, but they also had to ensure a favorable outcome of their actions [22] as well as attaining specific performance incentives $[7,10]$. Within PVM public value is realized through collaboration in networks of public and private parties [5, 23]. Public accountability is thus pluriform: public officials need to perform according to the law, societal values, political norms, professional standards, and citizens' wishes - requiring a new way of working [12]. Hence, the emphasis on transparency of public processes within PVM [24,25].

PVM has a different view on what constitutes governments and how public value is formulated compared to the bureaucratic and NPM paradigms. It emphasizes that public value creation happens as a process of continuous assessment determining whether the actions of public officials will lead to public value - either directly to 
citizens or by strengthening the role of the public sector [15]. PVM is thus an attempt of creating an integrated and holistic vision on value for society by collaboration of public and private parties in networks $[5,12]$. Hence, IT is considered central to PVM in order to coordinate these actions [10]. It is, therefore, often emphasized that within the public value framework, outcome, rather than output is realized [19,26]. Three characteristics of PVM can thus be distinguished: the definition of public value by through dialogue, the continuous assessment of their actions by public officials determining whether public value is attained, and the coordination of actions within networks of public and private parties supported by the use of IT.

\section{$3 \quad$ Research Method}

To investigate t-government efforts to find whether they lead to the outcomes of transformation outlined in the PVM paradigm, a case study from the Netherland is examined. This case study concerns the adoption of the international financial reporting standard XBRL (acronym of eXtensible Business Reporting Language) for financial reporting, based on a uniform taxonomy NT (Dutch taxonomy) and a process infrastructure that can be used to exchange information between businesses and the government. Financial reporting comprises all legally required information provisioning of businesses to the government. It is considered an appropriate case for investigating t-government, as it captures the use of information technology to realize public sector transformation. Furthermore, it is a very long-term project, as it started in 2004 and it is expected to continue at least into 2013, when the use of the XBRL standard for specific reporting processes will become obligatory.

A retrospective view on the case was created by carrying out fifteen semistructured interviews over the course of January and February 2010, which were complemented by three interviews in September 2011 to update the case study. The group of fifteen interviewees comprised three project managers of government organizations involved in implementing and maintaining the government infrastructure and systems for XBRL, five representatives of businesses from different sectors and varying size for understanding the user perspective, three accountants of various intermediaries, two representatives of software companies developing software packages for financial reporting, and two bank managers that are currently implementing XBRL in their organizations. The validating interviews were held with a project manager responsible for XBRL implementation and two researchers that have been involved in disseminating knowledge about XBRL. All interviews lasted between one hour and an hour and half. Most interviews were conducted by two researchers comparing results afterwards; some were conducted by one interviewer.

The interviewees were asked questions on the changes that were made in all aspects of government - and on the side of businesses and intermediaries. To determine in which ways transformation takes place, inquiries were made into all aspects of the PVM paradigm. Firstly, the objectives of the case study were determined, followed by the outcomes that were achieved. Secondly, the operational changes in the processes within government and the private sector were looked at to 
see whether any major changes or transformations could be observed. Thirdly, the organizational structure was looked at to find out how actions are coordinated and how accountability is organized. The purpose of these inquiries is to find out to what extent the objectives of PVM are achieved by this t-government effort.

\section{$4 \quad$ Case Study}

The introduction of the Dutch Taxonomy (NT) based on the international XBRL standard set out to standardize the process of legally required financial reporting by businesses in 2004. Instead of all government agencies defining their own requirements for financial reports, a taxonomy was created to harmonize definitions used by the Dutch government in the financial domain. Furthermore, a common process infrastructure is developed that is to be used for submitting all financial reports. Although the XBRL standard can be used for financial reporting across many sectors, the current project set-up includes a few specific reports: (profit) tax filing at the Inland Revenue Service (IRS), the submission of financial year reports at the Chamber of Commerce and the submission of data to the national bureau for statistics (CBS). In the private sector, a consortium of banks is developing a Banking Taxonomy (BT) to allow for automatic handling of credit applications using XBRL.

The process infrastructure developed to facilitate data exchange consists of a unified gateway for bulk data to government information systems. While the current structure of organizations concerned with financial reporting can be defined as a hierarchical command-and-control situation in which the government agencies enforce their standards onto the market, XBRL implementation is expected to allow for the creation of value chains across a network of organizations. As generating financial reports will be done using an open standard, organizations are able to innovate and new applications may emerge as well as new organizations developing new services. This likely results in a new situation in which government agencies remain in control of the interpretation of financial data and the decision-making process, but the process of creating reports will take place within a networked structure that enables innovation.

In 2006, to support the development of the NT a generic infrastructure project was started drawing up requirements for the functionalities necessary for a new process infrastructure for financial reporting based on XBRL. When the first version of the NT was ready and the plans for the process infrastructure were published, the three public agencies (IRS, Chambers of Commerce and CBS) signed an agreement to implement XBRL. This agreement was also signed by representatives of businesses, accountants and software vendors to stimulate the use of XBRL for financial reporting. Simultaneously, in line with political priorities at that time, the project was appointed to contribute to the central government agenda to achieve an administrative burden reduction of businesses. In 2007, the central government estimates that around 350 million euro's worth of administrative tasks of businesses can be cut and around a million tax filings using XBRL will be achieved yearly by 2008. 
However, the agreements of 2006 were not achieved. Therefore, in 2010 changes were made in the governance structure of the implementation program. A strong focus on the implementation was adopted by the organization guiding the changes, which also involved private parties. The process infrastructure developed for exchanging data based on XBRL was to be developed and maintained by the central government IT maintenance agency (Logius). Furthermore, the IRS decided to use the program to implement system-based control to improve compliance management. System-based control allows for checking the physical processes of organizations. By tapping into process information of companies it automatically checking whether these processes comply with regulations. Furthermore, to increase the quality of the financial reporting processes, the IRS started to phase out its old reporting processes. To spur developments, the use of the XBRL standard will become obligatory for specific streams of financial reporting in 2013.

\section{$5 \quad$ Findings}

The SBR case was investigated to determine whether any transformation is taking place by looking at the characteristics of PVM. The case study findings are summarized in table 2.

Table 2. Characteristics of PVM identified in the case study

\begin{tabular}{|l|l|}
\hline $\begin{array}{l}\text { Main purpose of the } \\
\text { government }\end{array}$ & $\begin{array}{l}\text { The improvement of financial reporting can be seen as creating } \\
\text { public value. }\end{array}$ \\
\hline $\begin{array}{l}\text { Role of the } \\
\text { government }\end{array}$ & $\begin{array}{l}\text { XBRL set out to steer private parties to carry out public goals in } \\
\text { NPM style by creating output targets. After Logius took over, the } \\
\text { role of the government turned into serving and empowering, } \\
\text { ensuring that the parties involved will benefit from the } \\
\text { implementation. }\end{array}$ \\
\hline Public sector ethos & $\begin{array}{l}\text { Rather than creating a law upfront that businesses will have to } \\
\text { follow by implementing XBRL, a joint agreement was made that } \\
\text { allows for collaboration between the public and the private sector. }\end{array}$ \\
\hline $\begin{array}{l}\text { Formulation of } \\
\text { public value }\end{array}$ & $\begin{array}{l}\text { XBRL implementation set out as a project to create value for all } \\
\text { parties involved: administrative burden reduction for businesses and } \\
\text { by advancing compliance controls for government organizations. }\end{array}$ \\
\hline Role of the public & Businesses are involved in policy formulation and implementation. \\
\hline $\begin{array}{l}\text { Role of public } \\
\text { officials }\end{array}$ & $\begin{array}{l}\text { While public officials keep having to follow procedures, and deliver } \\
\text { cost-effective services, they will also have to attune their actions } \\
\text { with those performed by officials in other organizations to create } \\
\text { value. }\end{array}$ \\
\hline $\begin{array}{l}\text { Discretion and } \\
\text { motivation of } \\
\text { administrators }\end{array}$ & $\begin{array}{l}\text { Both NPM and PVM characteristics can be observed: the creation of } \\
\text { innovative services can be considered entrepreneurial, and by } \\
\text { implementing horizontal control public officials will have more } \\
\text { discretionary room to attain their objectives. }\end{array}$ \\
\hline
\end{tabular}


Table 2. (continued)

\begin{tabular}{|l|l|}
\hline $\begin{array}{l}\text { Mechanisms for } \\
\text { achieving policy } \\
\text { objectives }\end{array}$ & $\begin{array}{l}\text { The XBRL standard is not implemented hierarchically, although it is } \\
\text { spurred by making it obligatory by 2013. Until then, implementation } \\
\text { depends on public and private parties implementing XBRL to serve } \\
\text { their own needs, through governance performed by Logius. }\end{array}$ \\
\hline Accountability & $\begin{array}{l}\text { Public officials remain accountable to elected politicians, but at the } \\
\text { same time a pluriform form of accountability emerges, in which } \\
\text { they are accountable not only to the law, but also to the political } \\
\text { norms of administrative burden reduction, professional standards of } \\
\text { compliance control, and business interests of making compliance } \\
\text { easier. }\end{array}$ \\
\hline $\begin{array}{l}\text { Organizational } \\
\text { structure; service } \\
\text { delivery }\end{array}$ & $\begin{array}{l}\text { What remains hierarchical is the relation between government and } \\
\text { businesses: businesses will have to comply with government } \\
\text { regulations. At the same time, through the horizontal control, a } \\
\text { networked structure will emerge in which businesses become } \\
\text { partners of the government to comply with reporting regulations. }\end{array}$ \\
\hline
\end{tabular}

Regarding the first characteristic of PVM - the definition of public value through dialogue - the implementation of XBRL aims to create value by introducing a standardized process for reporting. Rather than being a political objective, the implementation of XBRL, the NT and the process infrastructure are meant to be beneficial for both the public and the private organizations involved. Through the common agreement in 2006 the government set out to empower businesses and government organizations rather than being only involved in policy-making and implementation. Furthermore, Logius aimed to achieve implementation by involving private parties rather than by enforcing implementation. Thus, public value was defined and created in a collaborative manner rather than that it was enforced by the government.

The second characteristic is the introduction of the continuous assessment of whether public value is attained for citizens directly or by strengthening the public sector by public officials. XBRL implementation aims to do both. On the side of the government, system-based control will lead to a continuous assessment of whether businesses are compliant. At the same time delivering public value directly to businesses by realizing administrative burden reduction through standardized reporting also strengthens the role of the government in the network. While businesses are no longer merely customers, they also influence the governance process. Furthermore, system-based control requires more room for discretionary power for public officials that, instead of following fixed procedures use IT to tap into process information of businesses and perform compliance control based on risk profiles. Among the factors that determine the risk profile is the trust generated by the businesses by complying with the regulations. If they comply for a longer period of time, their risk profile will be given a status in which fewer checks are performed by the IRS. 
The coordination of actions within networks of public and private parties is the third characteristic of PVM. It includes the shift from hierarchically oriented public administrations to a networked structure in which public and private parties collaborate. While policy formulation indeed takes place through a process of governance, the other two characteristics cannot be seen to in place. Firstly, the nature of the relation between the government and businesses regarding financial reporting does not lead to a fully networked structure as governments remain in control of checking compliance of businesses. Secondly, regarding accountability, this still takes place large in the bureaucratic style of following procedures. Although public officials are responsive to more than just the procedures when performing horizontal control, it remains important. An important reason is that procedure accountability is a means to ensure equity. Thus, while the first and the second set of characteristics of PVM are in place in the case study, this is not the case for the third set of characteristics related to the organizational structure and accountability.

\section{Discussion}

From the case study it becomes clear that many characteristics of PVM are likely to be achieved by t-government. However, it cannot be concluded that a transformed organization will now be in place as a fully developed networked structure is not in place, nor is accountability transformed. Instead, it is still mainly vertically oriented and focused on following procedures. Thus, t-government in this case is not seen to be the realization of a fully transformed organizational structure (as government and businesses essentially keep the same roles as before), but rather to a process of governance by Logius, ensuring that the desired quality of the processes within the network is realized. This governance focuses on involving different - also private parties in order to implement the desired changes.

Furthermore, realizing accountability in the way it is defined by PVM is expected to lead to problems for three reasons. Firstly, it will become much more difficult for public officials to be accountable if they have to adhere to multiple procedures, demands, and standards. Secondly, as the new forms of compliance control by the IRS (horizontal control) are expected to lead to the continuous assessment of whether public value is created, it requires that public officials are much better trained than before to be able to make decisions within this complex set of requirements. One of the interviewees already indicated that this represents a challenge for the IRS as they expect that will have to hire more highly educated officials performing the compliance controls. Thirdly, an issue that may become problematic is the realization of equity. The main reason for bureaucracies to use procedure accountability is to ensure that public officials remain neutral (as they are able to do their work in different political realities), but also to not be able to favor individual citizens. Creating more discretionary room thus enables public value creation, but it also requires additional actions to ensure equity.

A main limitation of this study is that this case study is an innovative example of t-government. Other examples may give very different results. Therefore, to be able to 
generalize these findings, other cases in and outside of the Netherlands may need to be looked into. Especially as the XBRL implementation is considered an innovative case in the Netherlands, it is important to see whether the objectives of PVM are also observed in other cases of t-government.

\section{Conclusion}

T-government has the purpose of transforming the public sector. While e-government mainly focused on realizing the objectives of New Public Management (NPM), tgovernment aims to achieve the objectives of Public Value Management (PVM). PVM is concerned with the formulation of public value through a dialogue between public organizations as well as citizens and businesses. Furthermore, it aims to create public value through a continuous assessment of which value is being created either for citizens directly or to strengthen the role of the government. Finally, it aims to create public value by coordinating actions within networks of public and private organizations, supported by IT. This paper set out to find whether t-government achieves the objectives of PVM by looking at a case study from the Netherlands: the implementation of the XBRL standard for financial reporting.

The case study shows that public value is being created both by creating value for businesses as well as to strengthen the role of the government. Furthermore, public officials will get more discretionary room to assess whether businesses are compliant. However, a networked structure and a pluriform form of accountability are not observed. Rather than being a mechanism for creating transformed organizations, $\mathrm{t}$ government is thus an instrument for setting up governance in networks in order to realize the desired changes. To fully realize PVM professionalization of public officials is necessary as well as to make public processes more transparent. Further research should focus on whether professionalization and transparency contribute to realizing the objectives of PVM through t-government. Furthermore, other cases of tgovernment should be investigated to find whether PVM is also observed in less innovative cases.

\section{References}

1. Chatfield, A.T.: Public Service Reform through e-Government: a Case Study of 'e-tax' in Japan. Electronic Journal of e-Government 7, 135-146 (2009)

2. Dawes, S.S.: The Evolution and Continuing Challenges of E-Governance. Public Administration Review (Special Issue on The Quest for High-Performance Administration) 68, S86-S102 (2008)

3. Cordella, A., Iannacci, F.: Information systems in the public sector: The e-Government enactment framework. Journal of Strategic Information Systems 19, 52-66 (2010)

4. Bourgon, J.: Responsive, responsible and respected government: towards a New Public Administration theory. International Review of Administrative Sciences 73, 7-26 (2007)

5. Stoker, G.: Public Value Management A New Narrative for Networked Governance? The American Review of Public Administration 36, 41-57 (2006) 
6. Osborne, D., Gaebler, T.: Reinventing Government: How the Entrepreneurial Spirit is Transforming the Public Sector. Addison-Wesley, Reading (1992)

7. Goldfinch, S., Wallis, J.: Two Myths of Convergence in Public Management Reform. Public Administration 88, 1099-1115 (2010)

8. Irani, Z., Elliman, T., Jackson, P.: Electronic transformation of government in the UK: a research agenda. European Journal of Information Systems 16, 327-335 (2007)

9. Fountain, J.E.: Paradoxes of Public Sector Customer Service. Governance: An International Journal of Policy and Administration 14, 55-73 (2001)

10. Dunleavy, P., Margetts, H., Bastow, S., Tinkler, J.: New Public Management Is Dead Long Live Digital-Era Governance. Journal of Public Administration Research and Theory 16, 467-494 (2005)

11. van Veenstra, A.F., Klievink, B., Janssen, M.: Barriers and impediments to transformational government: insights from literature and practice. Electronic Government. An International Journal 8(2-3), 226-241

12. Moore, M.H.: Creating Public Value: Strategic Management in Government. Harvard University Press, Cambridge (1995)

13. Denhardt, R.B., Denhardt, J.V.: The New Public Service: Serving Rather than Steering. Public Administration Review 60, 549-559 (2000)

14. O'Flynn, J.: From New Public Management to Public Value: Paradigmatic Change and Managerial Implications. The Australian Journal of Public Administration 66, 353-366 (2007)

15. Cresswell, A.M., Burke, G.B., Pardo, T.A.: Advancing Return on Investment Analysis for Government IT. A Public Value Framework. Center for Technology in Government (2006)

16. Bannister, F.: Dismantling the silos: extracting new value from IT investments in public administration. Information Systems Journal 11 (2001)

17. Pollitt, C., Bouckaert, G.: Public Management Reform. A Comparative Analysis. Oxford University Press, Oxford (2004)

18. Weber, M.: Wirtschaft und Gesellschaft, Grundriss der Verstehende Soziologie, 5th revised edn. Studienausgabe, Tubingen (1972 (1920))

19. Alford, J., O'Flynn, J.: Making Sense of Public Value: Concepts, Critiques and Emergent Meanings. International Journal of Public Administration 32, 171-191 (2009)

20. Sager, F., Rosser, C.: Weber, Wilson, and Hegel: Theories of Modern Bureaucracy. Public Administration Review 69, 1136-1147 (2009)

21. Fountain, J.E.: Paradoxes of Public Sector Customer Service. Governance: An International Journal of Policy and Administration 14(1), 55-73 (2001)

22. Poulsen, B.: Competing Traditions of Governance and Dilemmas of Administrative Accountability: the Case of Denmark. Public Administration 87, 117-131 (2009)

23. Castells, M.: The Rise of The Network Society, 2nd edn. Blackwell Publishing, Cambridge (2000)

24. Bertot, J.C., Jaeger, P.T., Grimes, J.M.: Using ICTs to create a culture of transparency: Egovernment and social media as openness and anti-corrupution tools for societies. Government Information Quarterly 27, 264-271 (2010)

25. McDermott, P.: Building open government. Government Information Quarterly 27, 401$413(2010)$

26. Karunasena, K., Deng, H., Singh, M.: Measuring the public value of e-government: a case study from Sri Lanka. Transforming Government: People, Process and Policy 5, 81-99 (2011) 